\title{
The Bridge: Redux-The Breakdown of Normative Conviviality
}

\author{
Per-Markku Ristilammi
}

On 12 November 2015 the Swedish government decided to impose austere measures in order to stem the influx of refugees over the Öresund Bridge. ${ }^{1}$ Implemented from 21 November onwards, border controls were applied where the police entered trains at the first stop on the Swedish side of the border. Some weeks later, on 4 January, shipping and train companies were required to conduct ID controls prior to allowing people to pass into Sweden-later obligatory passport controls were imposed for all who crossed the border. For the citizens of Sweden and Denmark this was something that they had not experienced for generations. Even before the Schengen Agreement, the Nordic passport union had meant that Nordic citizens could travel freely between countries. Now this was no longer the case.

An unprecedented number of refugees had sought asylum in Sweden because of the civil war in Syria and the instability in Afghanistan and Iraq. Families and individuals that had survived perilous journeys across

P.-M. Ristilammi $(\bowtie)$

Faculty of Culture and Society, Department of Urban Studies, Malmö University, Malmö, Sweden

e-mail: per-markku.ristilammi@mau.se

(C) The Author(s) 2020

O. Hemer et al. (eds.), Conviviality at the Crossroads, https://doi.org/10.1007/978-3-030-28979-9_10 
the Mediterranean and the so-called Balkan route, had turned up at the Swedish borders. In the weeks before the decision to close these borders, Swedish media had been overrun by representations of people arriving at the central railway station in the city of Malmö- the endpoint of the bridge connection. The bridge thus had become a symbol for Sweden's open borders with a large number of volunteers from different non-governmental organisations (NGOs) waiting to help and guide incoming refugees (see Chapter 9). The city archive in Malmö took the initiative to document the convivial activities pertaining to interactions between asylum seekers, the authorities and the NGOs. ${ }^{2}$ However, with the introduction of border controls, this aura of openness was suddenly breached. From representing connectivity, the Öresund Bridge suddenly transformed to representing a point of defence against those in need of asylum.

In this chapter the concept of conviviality will be used as an analytic concept around which recent developments concerning the changing role of state borders in Europe will be discussed. Recent discussions around conviviality have highlighted tensions in the various ways the concept has been used. Originally used by Paul Gilroy (2004) as a concept that concentrates on modes of togetherness against the backdrop of social, racial and religious conflicts and tensions, conviviality now has more recently proliferated several different, somewhat contradictory, discussions (Valluvan 2016). Normative and prescriptive uses of the concept have been critiqued as hiding underlying social and racial inequalities and thus avoiding the political dimension (Nowicka and Heil 2015).

One important line of discussion has largely been conducted on the basis of empirical research that has concentrated around the social problems within "multi-cultural" parts of European cities. The notion of conviviality has therefore not been utilised in a more general sense. This chapter aims to highlight a specific kind of normative state-driven conviviality through the example of the Öresund Bridge, in order to show how the concept of conviviality can be used in an analysis of changing roles, or what I propose to call states of the state. The bridge and the surrounding region was part of a bi-national project of conviviality at its inauguration in 2000 (Ristilammi 2000 ), but 15 years later border controls signalled a breakdown of this specific form of conviviality. This chapter seeks to show, with ethnographic examples from border-crossing experiences at the bridge in 2000, 2015 and the present-day, how this breakdown of conviviality opens up for a new form of biopolitical regime at the border, turning the bridge into a zone of the abject (Foster 2015). 


\section{Before: The Convivial Border Region ${ }^{3}$}

When inaugurated on 1 June 2000, the bridge was hailed as a commemoration of a new Europe, a Europe of regions, with a diminished role to be played by nation-states. Processes of economic and cultural globalisation meant that the old Europe and its borders belonged to the past, surpassed by inevitable historical forces. The Schengen Agreement, with its focus on the free movement of labour and capital, was a political symbol of this new order. Old differences and strifes were to be forgotten with the heads of states of Sweden and Denmark evoking a shared history of conviviality between them at the bridge's inauguration-conveniently omitting the fact that the greatest number of wars between any two European countries had actually been fought between Denmark and Sweden. However, in the year 2000, all such conflicts were forgotten and the two countries joined in what was newly coined as the Øresund/Öresund Region.

A string of public events was launched in order to celebrate this newly pronounced regional conviviality. ${ }^{4}$ Citizens on both sides of the border were invited to partake in events at the bridge, providing spaces where collective feelings could become linked to the new region. One such events opened the bridge up to pedestrians letting them meet and mingle under the impressive 204-meter-high pylons at the centre of the bridge. Another event was a half-marathon where runners traversed the bridge and became part of a kinaesthetic experience - an event where runners blended impending exhaustion with the visual impact of being 60 meters above the water below (Ristilammi 2002b).

The biggest event - the inauguration of the bridge-was televised live. Audiences waved Danish and Swedish flags, symbolically underscoring the orchestration of border conviviality. Two trains coming from opposite directions met at the middle of the bridge, royalty descended from both trains and greeted one another at the border. Event organisers wanted to provide a 5-minute broadcast for $\mathrm{CNN}$ - they actually were given $15 \mathrm{~min}$ utes of air time. At the same time, the bridge became entangled in a collective kinesthetic, emotional and medialised experience of state-induced conviviality leading to collective memories being formed for those who had taken part in events (Ristilammi 2002a).

These memory processes connected to collective events start with an overflow of meaning that transcends lexical discourse. The statement, "You should have been there", marks the importance of the event. Some events become so important that words are "not enough" to describe them. 
They enter into an affective realm which is still simultaneously connected to a discourse of conviviality (Wetherell 2015). This excess of meaning solidifies into objects and places channelling collective forms of meaning and creating a sense of shared history (cf. Ristilammi 2000).

One way in which history was evoked in the event management process was through a notion of modernity revisited. It was not a return to an economy built on an industrial mode of production. Malmö had been a city with a strong industrial heritage, with ship-building industries located on its waterfront. The symbolic dismantling of this heritage took place in 2002 when a large gantry crane, the Kockums Crane, was dismantled and shipped to South Korea. ${ }^{5}$ At this time, the new and symbolic landmark of the bridge had been in place for 2 years. The Öresund project had an officially branded book with the following text on its cover:

In July 2000 the opening of a fixed link between Copenhagen, Denmark and Malmö, Sweden will herald the beginning of a new era for northern Europe. It will be the opening of a new region. The opening of countless possibilities and opportunities for inhabitants, travellers and businesses. The start of a new future.

By evoking a new future, the spectral apparition of an old future was conjured in the form of the failure of the old industrial modernity to meet the economic realities of the present. The city of Malmö was to rise as a phoenix from its industrial past, aided by this new region.

As an impressive piece of infrastructure, the bridge itself was a triumph of up-to-date industrial techniques, but the future management of the bridge was caught in the trappings of a new neoliberal, seemingly post-industrial, economy. Exhaustive media attention on the number of vehicles crossing the bridge was akin to the kind of monitoring usually reserved for companies on the stock market. So, on the one hand the building of the bridge was a return to large-scale investments in infrastructure, something that was characteristic of industrial modernity. On the other hand, this very return created a framing for the different branding techniques so prevalent in a neoliberal economy. The industrial monumentality of the bridge thus formed a very ambiguous backdrop to the different inaugural events associated with its opening.

The insistence of the new neoliberal economy for constant change, connected to the need for brand stability, was perfectly merged within the images of the stable bridge and the constant stream of people moving across 
it. The infinity symbol $(\infty)$ was superimposed on maps of the Öresund Region in order to conjure up the notion of the region as a growth machine with perpetual mobility. ${ }^{6}$ The notion of conviviality between nations built on historical ties, evoked in the opening ceremonies of the bridge, slowly gave way to a togetherness built on commerce and trade.

\section{Liquid Modernity and the Formless State}

In this frame of mind, national identity belonged to an older era where the state embodied stability and security, both inwards and outwards, but now a specific formlessness of the state resulted from what could, in Bauman's terms, be called a liquid modernity (Bauman 2000). Mobility across the bridge was to forge new hybrid identities, with the states assumed to be pliable enough to accommodate such a change. With an international airport at one of the ends of the bridge, the thought was to attract international capital and investment, while attending to the needs of those that Nigel Thrift called the fast subjects, the embodiments of international investment capital (Thrift 1996). The emphasis on speed, mobility and liquidity, seemed to demand states with loose contours, that could adapt to flows of capital. From the viewpoint of conviviality, the togetherness in the region could not be too strong so as to hinder the adaptability of the work force. A specific balance had to be struck when organising projects, linked to the opening of the bridge, that were associated with identity. Care would have to be taken not to bolster overly nationalistic sentiments when the symbolic forces of the nation states, such as royal houses, were evoked.

From a political perspective, the event-making process, the process of co-organising events on the bridge, was clearly a case of normative conviviality promoted on the state-state level with projections into the future about a specific Öresund identity, not only in terms of branding, but also as a real possibility for resident identity in Sweden and Denmark, aimed at a reformulation of the modernity project into a new liquid form. One event, a collaboration between art institutions on both sides of the border, called "The Culture Bridge", was meant to celebrate the role of art and history in the region. The "Culture Bridge" was supposed to be a coming together in the name of Nordic modernities-while being steeped in history the event was a very future-oriented enterprise. One of this event's highlights was a celebration, in the form of a theatre performance, of the 100-year anniversary of Arne Jacobsen, a futurist Danish architect and the designer of iconic 
design classics, such as the The Swan and The Ant chairs. Öresund's identity was clearly to be a modernist one with weak ties to nationalities. The aim of the normative conviviality of state-driven events was to balance the opposing forces of nationalism and seamless liquid modernity, but risked entering into another state of state, one that I would call a plasmatic one. The plasmatic state could be seen as a short lived, volatile state of state, one which eventually must return to solidity or liquidity, or otherwise threaten the state itself. ${ }^{7}$

A few years after the opening of the bridge, the situation was bleaker for the consortium that had built it. The number of cars crossing the bridge, which was used to measure its economic success, failed to reach the expected 11,000 per day, with the number of people travelling to work from one side of the bridge to the other also falling well below expectation. The growth machine seemed to be coming to a halt. In many ways, the notion of a new future had given way to a feeling of returning to the struggling present-day - the only difference was that now there was an expensive bridge to manage. Events were no longer used in order to manage popular support for the bridge. Closing the Öresund connection during high winds and vehicle breakdowns in the alternative tunnel proved that the bridge's construction was vulnerable, both practically and symbolically.

Also visible, this time on the political plane, was an increasing emphasis placed on the differences between states. The ever-increasing restrictions associated with Danish migration policy created concerns at the Swedish national political level, something that led politicians to use Denmark as a negative example. Likewise, Danish politicians and intellectuals used Sweden as an example of a country where political correctness prevailed at the expense of freedom of speech. Differences, not conviviality, seemed to be symbolised by both the bridge and region. Commuters and other travellers still continued to use the bridge, as did the "fast subjects" that populated executive lounges at Copenhagen Airport, but the rhetorical power of the bridge and its associated region started to disappear from 2010 onwards.

At this stage the bleak afterglow from the bridge's opening was considered a metaphor for the internationally successful TV crime series "The Bridge", where differences between neighbouring nations were used for dramatic effect (Askanius 2017). The characters in the series conveyed an underlying feeling of cultural differences between neighbours, highlighting national character traits not so easily overcome. The series pictured a challenged conviviality, whether state-driven or not. The different police 
bureaucracies of the two states was an illustration of the prevailing importance of national difference with the bridge depicted as a dangerous opening, a liability in the armour of the state, hovering between the liquid and the plasmatic - a threat.

\section{Now}

For refugees in the winter of 2015 , crossing the bridge was another kind of event, entering an affective realm where the excess of meaning was not something designed to foster regional feelings, but instead where excruciating experiences of traumatic passages were invoked. Voices heard over tannoys in train carriages pulling in to Hyllie station on the Swedish side of the border made it clear to everyone, commuters, tourists and refugees alike, that the power of the state was to be imposed on them in the form of very specific border crossing rituals ${ }^{8}$ - guards standing at wire fences ready to check identity papers; police, some with dogs, entering the train, scanning faces, comparing them with pictures and focussing the gaze of the state on some faces more than others (Peterson 2017). Commuters became tired of presenting their documents and tourists were perplexedtension began to rise. The biopolitical state machinery performed its task, to regulate the nature of the bodies entering the jurisdiction of the state, by pushing those that were unwanted into the zone of the abject (Foucault 1978; Foster 2015) and by neutralizing any notion of normative conviviality. Embodied in the form of border guards and police, the mythical body of the state, materialized in its spectral form (Gil 1998: 143f.). For some of those that passed the border the scrutinizing eye of the state morphed into the realm of electromagnetic imagery surpassing the boundaries of one's body (x-rays of knee joints), creating truth effects about biological age. ${ }^{9}$

\section{States of the State in the Öresund Region}

One problem, evident in the construction of the region even before events of 2015, was the difference between the notion of the diminishing importance of the nation-state, inspired by globalisation theories, and the everyday experiences of actors trying to facilitate cross-border initiatives, such as cooperation between universities or local tax authorities. It became obvious to these actors that the rules and regulations of the nation-state were still present in the minuscule workings of different bureaucracies. 
"Ways of doing things" had a profound impact on those who wished to have an everyday life that entailed crossing the border.

However, events in 2015 pushed the "stateliness" of the border to a new level. States entered into a plasmatic state that could not be sustained, a perceived "death zone" for the political structure of the state. Despite signals of hospitality radiating from the Swedish state, the sheer number of asylum seekers released something that could be called the "deep state". 10

Using Agamben's ideas one could argue that commuters found themselves in a double camp where the jurisdiction of both states created a grey area that was virtually impossible to navigate with any logic (Agamben 1998). What was left were the interests of "bare" states in "deep" mode.

One might see the enforcement of austere migration policies in the autumn of 2015 as a core activation of the Weberian iron cage (or more correctly the iron shell) "stablhartes Gehäuse", a bureaucracy that, in its last instance, is able to contain and shape the form of the state. The formless, or plasmatic (or even phantasmagoric), iteration of the neoliberal, neomodern state, shape shifted under pressure. Formlessness turned into the penal state (Barker 2017, 2018), a state not in flow, not liquid, but in regulatory mode, making distinctions, diagnosing, politicizing biology—acting out the machinations of the old modernity. ${ }^{11}$ This became even more evident with the treatment of refugees and their legal status. The region was an attempt to evoke the future, as a form of modernity revisited, where past ghosts of a monocultural society were re-evoked (cf. Hellström and Petersson 2002: 13). Derrida sees the return of past ghosts as a form of phenomenological conjuring trick (Derrida 1994: 125ff.), with the ghosts being conjured by personification and a suspension of time. And herein lie the possibilities associated with creating timeless spaces, perhaps not initially anticipated when creating a region.

The refugees, stripped of their legal rights, became trapped in a position both inside and outside the law, where their "spectral past" 12 survived and haunted both their dreams and the fears of the host-country (Diken and Bagge-Laustsen 2003). The authorities way of dealing with this "spectrality" was, and still is, spatial and temporal incarceration shielding the state from those both outside and inside of the national jurisdiction. In one sense we could view these spectralities as a form of phantom pain, of attachments lost and convivialities shattered.

The train pulling into the station takes the form of a phantom vehicle, never reaching its final destination, forever transporting refugees destined to remain in limbo. At least this was how the refugees were perceived in 
the autumn of 2015 , that is, forever on the run, never reaching their goal, always heading further north, abjected by the state. Thus, it is the state that decides the limits of the reach of conviviality. Embodiments of the state scan faces on the train looking for signs of ethnic alterity mixed in with the anxiety of the unwanted. The coach becomes a distributive vehicle for the "deep" state's core reflexes, the nervous system that works beyond politics (Taussig 1993).

In the weeks before these austere migration laws were enforced by the state, an exceptional mobilisation of civic hospitality took place on both sides of the border. Instead of the gaze of the "bare state", the notion of unconditional face-to-face meetings, in Levinas' sense, had been the guiding rule for the many volunteers who met migrants when they stepped off the trains (Levinas 1990). The central train station, a non-place, in Marc Augée's sense, ${ }^{13}$ had become a space of sanctuary where conviviality prevailed (Augée 1995). However, this was not the case for long. When the bridge was effectively closed to asylum seekers not carrying the proper documentation (the majority of them), this specific form of civil conviviality waned. ${ }^{14}$

It was obvious at this stage that the newcomers were not the "fast subjects" of liquid modernity but were something else. The "slow subjects" seemingly dragging their "spectral pasts" into secure/securitising camps within the neo-modern body of the state-not even forming part of the old modernity that was once created by the Nordic welfare states. When the face-to-face hospitality of common people was challenged by the closing of the border, asylum seekers became meaningless subjects to the state. When the refugee asks: What is the jurisdiction? The state answers: It depends on who you are! When the refugee asks: Who am I? The state answers: You tell me!

The "eye" of the state turned from a convivial disinterest, to a watchful scanning for unwanted bodies. The time/space-specific vantage point of Gilroy's iteration of conviviality was born in the convulsions of Western states entering into the formless, unsustainable death zone of the plasmatic state. The question is "How are the people without common pasts going to live together?" Now the pasts: cultural, ethnical, biological enter into the biopolitical sphere again. 


\section{The Bridge as an Abjective Infrastructure}

What was meant to be an infrastructure designed to foster economic growth, a virtual growth machine, turned into another form of regulatory machinery. The bridge became part of a biopolitical mechanism driven by state regulation and group interests.

Now the bridge embodies the return of sovereign territoriality, not in the form of the power of a sovereign, but in form of a state configured as a regulatory mechanism of power beyond politics. On an everyday scale the shapeshifting of the state has manifested itself in the regulatory bodies moving through trains, scanning faces and scrutinising documentation, with fleeting or permanent affect. Artefacts such as fences, yellow vests, digital cameras, passports and infrared cameras in the tunnel became part of a new form of power that reflected, not only the diminishing role of the region, but also a new form of state.

The bridge became part of an infrastructure where the "subordinate parts of an undertaking", namely the state, morphed into an iteration slowly shapeshifting all over Europe, rendering meaningless the "slow subjects" of the world. The normative conviviality from the age of transnational region building disintegrating into "bare mode" states with traces of conviviality being confined to the "normality" of the everyday life of commuters bearing the correct documents.

\section{Notes}

1. From Swedish government official website: http://www.regeringen. se/artiklar/2015/11/regeringen-beslutar-att-tillfalligt-aterinforagranskontroll-vid-inre-grans/ and http://www.regeringen.se/4ae76f/ contentassets $/ 23 \mathrm{c} 37 \mathrm{bl} 42 \mathrm{~cd} 54 \mathrm{~d} 658 \mathrm{~d} 660 \mathrm{dc} 5 \mathrm{ca} 27 \mathrm{afe} 5 /$ sarskilda-atgardervid-allvarlig-fara-for-den-allmanna-ordningen-eller-den-inre-sakerheten-ilandet-prop.-20151667.

2. From the City of Malmö official website: https://malmo.se/Kultur-fritid/Kultur-och-fritid-nyheter/2018-03-16-ANKOMST-MALMO.Roster-om-flyktingmottagandet-hosten-2015.html.

3 . The account and analysis of the events surrounding the bridge's opening in 2000 stems from my participation in the project "Frambesvärjandet av en transnationell region. En flervetenskaplig studie av Öresundsområdet”, led by Orvar Löfgren and Per-Olof Berg (see Berg 2000; Ristilammi 2002b, 2005a, b, 2006, 2007, 2010). 
4. At the time of the bridge's opening, at the beginning of the 2000s, the notion of events and event-making was en vogue among economical analyses connected to the so-called New Economy. Such events were new kinds of marketing and governance strategies connected to the volatility of the neoliberal economy precisely because they catered to emotions instead of calculative intellect (Ristilammi 2002b).

5. From Wikipedia: https://en.wikipedia.org/wiki/Kockums_Crane.

6. The concept of growth machine was initially coined by Harvey Molotch in the 1970s as way of critically describing the specific economic and social processes regarding land use leading to the growth of cities (Molotch 1976).

7. One apparition of the plasmatic state could be the "spectrality" that haunts the state in specific historical moments (Gil 1998: 143f.).

8. As Nancy Wonders has shown, all kinds of border crossings contain a performative dimension where bodies are being staged in very specific rituals (Wonders 2006).

9. MRI scanning of knee joints: http://www.bbc.com/news/world-europe42234585 .

10. The notion of the "deep state" was initially coined as a concept that described the power of the Turkish military.

11. This tendency of shapeshifting belongs to the realm of stasiology, where stasis contains the necessary tension between movement (kinesis) and firmness within the field of the political (Feldman 2015: 9ff.).

12. The baggage of experiences, memories, mourning and longing of refugees.

13. Although influential when published, describing places like airports as beacons of super-modernity, it also became criticized for omitting the fact that non-places also produce non-people.

14. This started before the demand for documentation. Pure exhaustion had taken its toll among the volunteers (see elsewhere in this volume).

\section{REFERENCES}

Agamben, G. 1998. Homo Sacer: Sovereign Power and Bare Life. Stanford: Stanford University Press.

Askanius, T. 2017. "Engaging with The Bridge: Cultural Citizenship, Cross-Border Identities and Audiences as 'Regionauts'." European Journal of Cultural Studies 22 (3): 1-20. https://doi.org/10.1177/1367549417722093.

Augee, M. 1995. Non-Places: Introduction to an Anthropology of Supermodernity. London and New York: Verso.

Barker, V. 2017. "Penal Power at the Border: Realigning State and Nation." Theoretical Criminology 21 (4): 441-457. https://doi.org/10.1177/ 1362480617724827. 
Barker, V. 2018. Nordic Nationalism and Penal Order: Walling the Welfare State. London and New York: Routledge.

Bauman, Z. 2000. Liquid Modernity. London: Polity Press.

Berg, P.-O., ed. 2000. Invoking a Transnational Metropolis: The Making of the Øresund Region. Lund: Studentlitteratur.

Derrida, J. 1994. Spectres of Marx, The State of the Debt, the Work of Mourning o the New International. London: Routledge.

Diken, B., and C. Bagge Laustsen. 2003. "Zones of Indistinction-Security, Terror and Bare Life." In Territories - Islands, Camps and Other States of Utopia, edited by A. Franke. Köln: Verlag der Buchhandlung Walther König.

Feldman, A. 2015. Archives of the Insensible: Of War, Photopolitics and Dead Memory. Chicago and London: The University of Chicago Press.

Foster, H. 2015. Bad New Days: Art, Criticism, Emergency. London and New York: Verso.

Foucault, M. 1978. The History of Sexuality. Volume 1, An Introduction/Michel Foucault; Translated from the French by Robert Hurley. New York: Pantheon Books.

Gil, J. 1998. Metamorphoses of the Body. Minneapolis and London: University of Minnesota Press.

Gilroy, P. 2004. After Empire: Melancholia or Convivial Culture? Abingdon: Routledge.

Hellström, A., and B. Petersson. 2002. Temporality in the Construction of EU Identity. Lund: CFE Working Papers.

Levinas, E. 1990: Time and the Other. Pittsburg, PA: Duquesne University Press.

Molotch, H. 1976. "The City as a Growth Machine: Toward a Political Economy of Place." The American Journal of Sociology 82 (2): 309-322.

Nowicka, M., and T. Heil. 2015. On the Analytical and Normative Dimensions of Conviviality and Cosmopolitanism. Tübingen: Eberhard Karls Universität.

Peterson, A. 2017. "Humanitarian Border Workers in Confrontation with the Swedish State's Border Making Practices: 'The Death of the Most Generous Country on Earth'." Journal of Borderlands Studies. https://doi.org/10.1080/ 08865655.2017.1402199. Published online November 17, 2017.

Ristilammi, P.-M. 2000. "Cultural Bridges, Events and the New Region." In Invoking a Transnational Metropolis: The Making of the Oresund Region, edited by P.-O. Berg, 95-108. Lund: Studentlitteratur.

Ristilammi, P.-M. 2002a. "Vitt ljus - Vitt brus: Om regionala födelsesmärtor." Come In-Go Out. Det 10. billede. Copenhagen: Kunstakademiets Arkitektskole, Fonden Kulturbro, Informations Forlag.

Ristilammi, P.-M. 2002b. "Ballonger och fantomkänslor.” In Öresundsbron på uppmärksambetens marknad. Regionbyggare i evenemangsbranschen, edited by P.-O. Berg and A. Linde-Laursen. Lund: Studentlitteratur. 
Ristilammi, P.-M. 2005a. "Afterthoughts on Modernist Necropoles." Ethnologia Europaea, 35 (1): 107-112.

Ristilammi, P.-M. 2005b. "Spectral Events: Attempts at Pattern Recognition.” In Magic, Culture and The New Economy, edited by O. Löfgren and R. Willim, 87-95. Oxford and New York: Berg.

Ristilammi, P.-M. 2006. "Stealth." Ethnologia Europaea, 35 (2): 88-90.

Ristilammi, P.-M. 2007. "Urban globalisering i Öresundsregionen. Mångkulturalitetens varierande grader av synlighet." In Öresundsgränser: Rörelser, möten och visioner i tid och rum, edited by F. Nilsson, H. Sanders, and Y. Stubbergaard, 352-368. Göteborg and Stockholm: Makadam Förlag.

Ristilammi, P.-M. 2010. "I brons skugga." In Regionauterna-Öresundsregionen frain vision till vardag, edited by O. Löfgren and F. Nilsson, 157-164. Göteborg and Stockholm: Makadam Förlag.

Taussig, M. 1993. The Nervous System. London and New York: Routledge.

Thrift, N. 1996. Spatial Formations. London: Sage.

Valluvan, S. 2016. "Conviviality and Multiculture: A Post-integration Sociology of Multi-ethnic Interaction.” Young 24 (3): 204-221. https://doi.org/10.1177/ 1103308815624061 .

Wetherell, M. 2015. "Trends in the Turn to Affect: A Social Psychological Critique." Body \& Society 21 (2). https://doi.org/10.1177/ 1357034 X14539020.

Wonders, N. 2006. "Global Flows, Semi-Permeable Borders, and New Channels of Inequality: Border Crossers and Border Performativity." In Border, Mobility and Technologies of Control, edited by S. Pickering and L. Weber. Dordrecht: Springer.

Open Access This chapter is licensed under the terms of the Creative Commons Attribution 4.0 International License (http://creativecommons.org/licenses/by/ $4.0 /$ ), which permits use, sharing, adaptation, distribution and reproduction in any medium or format, as long as you give appropriate credit to the original author(s) and the source, provide a link to the Creative Commons license and indicate if changes were made.

The images or other third party material in this chapter are included in the chapter's Creative Commons license, unless indicated otherwise in a credit line to the material. If material is not included in the chapter's Creative Commons license and your intended use is not permitted by statutory regulation or exceeds the permitted use, you will need to obtain permission directly from the copyright holder.

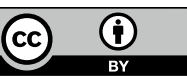

